Ankara Üniversitesi Türk Inkılâp Tarihi Enstitüsü Atatürk Yolu Dergisi S 27-28, Mayts-Kasım 2001, s. 263-283

\title{
Alman Kaynaklarında Türk Harf İnkılâbı ve Yankıları (Elçilik Raporları-Basın ve Diğer Kaynaklar)
}

\author{
Yrd. Doç. Dr. Ramazan ÇALIK* \\ Yrd. Doç. Dr. Ali Galip BALTAOĞLU*
}

ÖZET

Türkçe ve yabancı dillerde Türk Harf İnkılâbı hakkında pek çok araştırma yapılmıştır. Bunlar arasında R. Sonyel'in Ingiliz Gizli Belgeleri'inde Türk Yazı Devrimi ve Bilal Șimşir'in Türk Yazı Devrimi adlı çalışmaları ve Gülnihal Bozkurt'un 'Türk Harf Devrimi'nin Alman Arşiv Belgeleri'nde Değerlendirilmesi adlı bildirisi önem arz etmektedir. Bu çalışmalarda yazarlar harf inkılâbı ve Avrupa'daki etkisini vurgulamaktadırlar. Fakat Mustafa Kemal'in reform paketinin oluşmasına tşık tutan Alman kaynaklart çok az ve sınırlı kullanılmıştır. Bu makalede mevcut Alman kaynaklart, özellikle de Alman diplomatlarının raporları temel alınarak Türk Harf İnkılâbı değerlendirilmiştir. Bu raporlar reform sürecinin anlaşılması bakımından çok önemlidirler. Çünkü reformların gerçekleşmesinden yıllar önce söz konusu reformların karakteri vurgulamaktadır. Alman Büyükelçilerinden Kühlmann (1917'de Büyükelçi) ve Türkiye Cumhuriyeti'nde ilk Alman Büyükelçi Nadolny'nin raporları burada geniş bir şekilde kullanılmıştır. Zira Kühlmann 1917'den itibaren Dil İnkılâbı'nın bir yol haritasını çizerken, Nadolny reformlar hakkında toplumdaki görüs, tartısma ve Mustafa Kemal'in icraatlarmı ve gelişmeleri ortaya koymaktadır.

Sonuç olarak Türk Harf İnkılâbına Alman ilgisinin maddî temellere dayandı̆̆ı ve reformların aldığı şekil ïzerinde etkili olmaya çalıştığı vurgulanmaktadır.

Anahtar Kelimeler: Arap Alfabesi, Latin Alfabesi, Harf İnkılabu, Alman kaynakları, Alman Büyükelçileri Kühlmann ve Nadolny, Osmanlı, Talat Paşa, Hüseyin Cahit, Mustafa Kemal.

'Celal Bayar Üniversitesi, Fen Edebiyat Fakültesi Tarih Bölümü, Öğretim Üyesi.

* Afyon Kocatepe Universitesi, Uşak Eğitim Fakültesi, İlköğretim Bölümü, Sosyal Bilgiler Öğretmenliği, Öğretim Üyesi. 


\title{
According To The German Archives Documents Turkish Language Reform And Its Impoct
}

\begin{abstract}
Turkish Language Reform has been the subject of many studies in Turkish and foreign Ianguages.same of the most important, amongs them, can be indicated as follows:the work of R.Salahi SONYEL, which is entitled as "Ingiliz Gizli Belgelerinde Türk Yazı Devrimi", that of Bilal ŞIMSSIR, entitled as "Türk Yazı Devrimi" and that of Gülnihal BOZKURT,entitled as" Türk Harf Devrimi'nin Alman Arşiv Belgelerinde Değerlendirilmesi".In these studies, the authors deal with Language Reforms and ist perception in Europei but they took into account in a limited way the German Sources which were significont for the reforms of Mustafa Kemal Atatürk.

In this article we have tried to evaluate the Turkisch Language reformon basis of the extant German sources, especially the reports of the German diplomats. These reports are of importance in underspanding the reform process, since they begin from as early as 1917, long before the Language reform was realized, outlines the would be characteristics of the reforms. The reports of the German ambassadors Kühlmann, the German ambassador to Ístanbul in 1917, and that of Nodoly, the ambassador in the Republican Period, are also used entensively in this article, because while Kühlmann pointedto the road map of the Language reform as of 1917. Nodalny reported of the opinions and arguments in the society about the planned reforms.It is concluded that the German interest in the Turkish Language reform was of financial nature, but also influenced the characteristics of the reforms.
\end{abstract}

Keywords: Language reform, Turkey, Turkish Alphabet, Kühlmann, Nadolny, Talat Pahsa, Mustafa Kemal Atatürk.

\section{Çalışmanın Amacı}

Alfabe inkılâbımız üzerine bugüne kadar yerli ve yabancı bir çok eser yazıldı. Hatta Bilal Şimşir, Türk Yazı Devrimi adlı eserinin dördüncü bölümünü, Dış Basında Türk Yazı Devrimi olarak sadece bu konuya ayırdı. Bu başlık altında o, Alman basını dışında bütün Avrupa basınına yer verdi. Ayrıca "İngiliz Gizli Belgelerinde Türk Yazı Devrimi" adıyla daha özel çalışmalar da yapıldı' ${ }^{1}$. Görüldü ki, tarihte köklü ilişkilere sahip olduğumuz I. Dünya Savaşı'ndaki müttefikimiz, bugün ise Avrupa Birliği Düşüncesinin ve projesinin lokomotifi olan Almanlar üzerine kayda değer ve sistemli bir

${ }^{1}$ Salâhi R. Sonyel, "Ingiliz Gizli Belgeleri'nde Türk Yazı Devrimi”, Türk Dili Dergisi, TDK Yayınlanı,Kasım 1979, Ankara, S.338, s.285-294. 
çalışma yapılmamıştır. Bu alandaki tek istisna, XII. Türk Tarih Kongresi’nde sunulan Gülnihal Bozkurt'un Türk Harf Devrimi'nin Alman Arşiv Belgeleri'nde Değerlendirilmesi adlı bildirisidir ${ }^{2}$. Bildiri, 1 Şubat 1927 tarihi'nde bașlayan, 31 Ocak 1928'de son bulan Nadonly raporlarının bir değerlendirmesini içermekte, daha önceki tarihi kesitlerden bahsetmemekte ve Almanların bu konudaki bakış açılarını tam olarak değerlendirmemizi sınırlamaktadır. Bunun dışında bildiri çok güzel ve orijinal bir çok malumatı da bize sağlamıştır.

İşte bizim çalışmamız, alanda görülen bu açık üzerine düşünüldü. Alman kaynaklarında Türk dil inkılâbı üzerine yazılanlar, yorumlar ve düşünceler makalemizin içeriğini oluşturdu.

Makalemizde Alman kaynakları değerlendirilmiştir. Genel anlamda, Alman büyükelçilerinin raporları ile Alman diplomasisinin harf inkılâbına tepkileri ortaya konulurken, Alman basını ve diğer Alman kaynaklarına da yer verilmiştir. Ayrıca, Almanların dil inkılâbımız üzerine ne düşündüğünün yanında beklentileri de değerlendirilmiştir. Metodik olarak kaynakların değerlendirilmesi gelişmelerin kronolojik sırasına sadık kalınarak yapılmıştır. Bu makale son derece sınırlı olarak Aralık 2003 tarihinde V. Uluslararası Atatürk Kongresi'nde bildiri olarak sunulmuştur. Aynı kongrede Mustafa Çolak'ın "İstanbul'daki Alman Büyükelçiliği Raporlarına Göre Mustafa Kemal ve Harf Ínkılabı" adlı bildirisi ve bu bildiride kullandığı kaynaklar da makalemizin içeriği ile doğrudan ilgilidir. Henüz yayımlanmayan, fakat yayınlanacak olan bu bildiriye de atıflarda bulunulmuştur. Çolak'm bu bildirisi gerçekten alandaki boşluğu dolduran nitelikli bir çalışmadır.

\section{Giriş}

Türkler tarih boyunca çeşitli harfler kullanmışlardır. Orta Asya'da kullandıkları Göktürk harfleri kendine özgüdür ve tarihteki tek istisnasıdır. Herhalde tarihte Türkler kadar farklı alfabeleri kullanan bir başka millet olmasa gerektir. Bu durum sanıyoruz Türklerin çok geniş bir coğrafyaya yayılmaları ve çok farklı kültür ve medeniyetlerle temasa gelmeleri sonucu ortaya çıkmıştır. Böyle bir tarihi seyrin çok hızlı bir kültür değişmeleri sürecini tetiklemesini de doğal karşılamak lazımdır. Girdiği ve vatanlaştırdığı topraklarda karşılaşılan medeniyet çevresinin kültürel gerekleri sonucu çok farklı harfler kullanan milletimizin bu eğilimlerinin temel sebebi de din faktörü olmuştur. Türkler mensup oldukları dinin gereği gördükleri alfabe sistemlerini kullanmayı adeta bir gereklilik olarak algılamışlardır. Ta ki, Latin kökenli harflerin kabulüne kadar! Türk Harf

2 Gülnihal Bozkurt "Türk Harf Devriminnin Alman Arşiv Belgeleri'nde Değerlendirilmesi" XII. Türk Tarih Kongresi, Kongreye Sunulan Bildiriler, C IV, TTK Ankara 1999, s.(1353-1361). 
İnkılabının iki temel nedeni vardı. Birincisi dilin ihtiyaçları ${ }^{3}$, ikincisi ise muasır medeniyeti yakalama arzusu. Türkler Müslümanlı̆̆ ${ }_{1}$ kabul ettikten sonra Arap harflerini kullanmaya başladılar. Alfabe inkılabı ile beraber ilk defa din faktörünü gözetmeden ve din değiştirmeden Latin esaslı alfabeyi kabul ettiler.

Türkleri alfabe inkılabına götüren sürecin matbaanın ülkeye getirilmesiyle başladığını söyleyebiliriz. Türk Kültürü 1730'larda İbrahim Müteferrika'nın yabancılara Türkçe öğretmek amacıyla hazırlayıp bastırdığ̆ bir gramer kitabının sonuna eklenmiş konuşma örneklerinde Lâtin kökenli harflerle tanıştı ${ }^{4}$. Bu ilk tanışmanın tarihin akışını değiştirmiş en büyük medeniyet aracı olan matbaanın, ülkeye girişi ile olması da herhalde tesadüfi değildir.

Ondokuzuncu yüzyılın ortalarından beri, Türklerde de Latin alfabesini kullanma eğilimi olduğunu biliyoruz. Özelikle II. Meşrutiyet Dönemi'nde dil ve dilin sorunları, dilde İnkılâp çabaları yoğun olarak gündeme geldi. Fakat Cumhuriyete gelinceye kadar bunu gerçekleştirmeye kimse cesaret edemedi. Cumhuriyetin kurulmasindan sonra da bu konuda basinda ve aydınlar arasında birçok tartışmalar oldu. Sonunda, $1928^{\circ}$ de Milli Eğitim Bakanlığı bir alfabe encümeni kurarak Arap harflerinin yerine Latin harflerine geçiş sürecini başlattı. Aynı yılın yazında Atatürk, İstanbul'da Dolma Bahçe Sarayı'nda bilgin ve aydın kişileri toplayarak bu konuyu ele aldı. Alfabe Encümeni'nce hazırlanan yeni harfler üzerinde çalışmalar tamamlandı. Latin harflerinden oluşan alfabeye son şekli verilerek İnkılap 1 Kasım 1928 tarihinde meclis kararı ise resmen gerçekleştirildi.

\section{Alman Kaynaklarında Türk Harf İnkılabı ve Yankıları}

\section{Alman Diplomasisi Raporlart}

a) 1917 yılındaki gelişmeler

Türkiye'deki Alman diplomasisi alfabe ve dil tartışmalarını Cumhuriyet'in Kuruluşu'nun çok öncesinden itibaren dikkatle takip etmiştir. İstanbul'daki Alman Büyükelçisi Richard von Kühlmann'ın' 8 Mart 1917'deki raporu son derece dikkat çekicidir.

\footnotetext{
${ }^{3}$ İlber Ortaylı, Türkçe konuşulan alanlarda iki değișim ve etkinin görüldüğünü ifade eder. Bunlardan ilki modernleşen ve büyüyen bürokrasinin standart imla ve yazı gereksinimi, ikincisi ise milliyetçilik fikri çerçevesinde gelişen dil araştırmalarıdır. Bu konuda bkz. "Tarihsel ve Toplumsal Nedenleriyle Türk Harf Devrimi" Atatürk Döneminin Ekonomik ve Toplumsal Tarihiyle Ilgili Sorunlar Sempozyumu. 14-16 Ocak, İstanbul 1977, s.408,409.

^ Faik Reşit Unat, "Lâtin Alfabesinden Türk Alfabesine", Türk Kültürü, C.II, S.23 Ağustos 1953.

5 Richard von Kühlmann 16 Kasım 1916'dan 24 Temmuz 1917'ye kadar Osmanl başkenti İstanbul'da Alman Büyükelçisi olarak görev yapmıştır.
} 
Kühlmann raporunda, Edebiyat çevrelerinde Latin harfinin kabulünü isteyen ve bu yenilik için kararlılıkla ortaya çıkan genç Türklerin varlığından bahsetmektedir. Bunların öncülerinden Hüseyin Cahit, Talat Paşa kabinesinde Maarif Nazırı olarak düşünülmüş, fakat Hüseyin Cahit, öne sürdüğü Latin alfabesinin kabulü şartı kabul edilmediği için, bakan olmamıştır. Ayrıca Talat Paşa kabinesinde bakanların çoğu bu yeniliğe muhalif kalmışlardır. Maarif Nazırı Şükrü Bey 22 tarihli İkdam Gazetesi'nde bakanlığın dilde yenileşmeyi öngören bir takım çabalar içinde olmadığını, Türkçe'nin transkripsiyonu için oluşturulan komisyonun zikredildiği gibi bakanlık tarafından oluşturulmadığını, gerçekte komisyonun üniversite çevrelerinden gelen talep üzerine ünlü edebiyatçı Ziya Gökalp'in önergesi ile kurulduğunu, amacının da Türk özel isimlerinin Latince matbaa harfleriyle yazımında birlikteliği oluşturmak olduğunu bildirmektedir. Bu Komisyonu teklif eden Ziya Gökalp, Arap harflerinin ilga edilmesinden yanadır. Hükümet, Hüseyin Cahit'in fikirlerinin yayılmasını yasaklamıștır. Yine Hükümet Bulgar hükümetinin ${ }^{6}$ Latin harflerini kabul kararının haber yapılmasını da basına yasaklamıştır. İslam Derneğinde iki yazının taraftarları arasında hiddetli bir tartışma vuku bulmuştur. Hukuk Fakültesinde profesör ve senatör olan Said, bir yandan Latin alfabesinin Avrupalılara Türk dilinin öğrenilmesini kolaylaștıracağını söylerken, diğer yandan bu olayın Türklerin millet bilincine ağır bir darbe olabileceğini belirtmiştir. Şeyhülislamlıkta danışman olan diğer bir konuşmacı Ebu'l ûlâ Efendi, planlanan yeniliğin ne milli politikayla ne de İslam diniyle ahenk sağlamayacağını ve İslam dünyasında Türkiye'nin konumunun sarsılabileceğini ifade etmiştir. Buna karşı diğer konuşmacılar Cenap Şahabettin, Celal Nuri ve Abdullah Cevdet Latin alfabesi lehinde konuşmuşlardır.

Bu bilgileri veren Kühlmann ilgi çekici yorumlar yapmaktadır. Örneğin verdiği bilgilere dayanarak yenilikçi görüşün önderi konumundaki Hüseyin Cahit ve arkadaşlarının hükümetin söz konusu reddini kabul etmeyecekleri ve Arap harflerine karşı mücadeleye bütün güçleriyle devam edeceklerini söylemektedir. Hükümetin baskı ve yalanlamalarının bir kez gündeme gelen alfabe meselesinin ilgili çevrelerde tartışılmasının engellenemeyeceği de ifade edilmektedir ${ }^{7}$.

\footnotetext{
${ }^{6}$ Burada muhtemelen elçi tarafından bir hata yapılarak, Arnavut hükümeti denileceği yerde Bulgar Hükümeti denmiştir. Kril alfabesi kullanan Bulgarların bu dönemde alfabe değişimi gibi bir tarihi süreçleri olmamıştır. Fakat Arnavutların böyle bir örnekliği vardır. 1879 'da Abdülhamit'in muvafakatiyle kurulan Arnavut cemiyet-i ilmiyesi'nin kabul ettiği ünlü lügatçi Şemsettin Sami'nin 26'sını Latin 10'unu yunan harflerinden aldığı ilk milli alfabe bir süre sonra yasaklanmış ve 1908'de Manastır'da toplanan Arnavut Dil Kongresi'nde tamamı Latin harflerinden oluşan bugünkü alfabe kabul edilmiştir.(s.389) Geniş bilgi için bkz. Mustafa L Bilge, “Arnavutluk” Md .TDViA, C.III, İstanbul 1991. (s.383-390).

${ }^{7}$ İstanbul Alman Büyükelçiliğinin Pera'dan yazdığı 8 Mart 1917 Tarih ve 164 nolu rapor, R. 13198. Türkei 134. Allgemeine Angelegenheiten der Türkei, vom 1. Januar 197 bis 31. Juli 1917 .
} 
Büyükelçi daha Meşrutiyet döneminde Latin harfini isteyen aydınları çok net bir cephe olarak tasnif etmekte ve bunların fikirlerinde sabit olduğunu, mücadele edeceklerini belirtmektedir. II. Meşrutiyet Dönemi'nde Latin harfleri yönünde görüş bildiren aydınların ve bunların mücadele azimlerinin, görüş ayrılıklarının somutlaştırıldı ̆̆ kaynaklarına geçmesi önemlidir. Kaldı ki, meşrutiyet döneminde net tavrını eserleriyle tescil eden Celal Nuri gibi şahsiyetlerin bu fikirlerini Cumhuriyet Döneminde aynı inançla savunamadığı zamanlar olduğunu da bilinmektedir ${ }^{8}$. Elçinin bilgilerini "malumatı olan çevrelerin iddia ettiği gibi" bir cümleye dayandırması, resmi bilgilerin dıșında kişisel istihbarat bilgilerini içerdiğini göstermektedir. Bu bilgilerin tarihçiler tarafından bu açıdan da önemle değerlendirilmesi gerektiği kanaatindeyiz. İstihbarat kaynaklarını bilmemekle beraber verilen bilgilerin sıhhati incelendiğinde oldukça şaşırtıcı sayılabilecek güvenilirlikte olduğunu görmekteyiz. Ziya Gökalp'in Arap harflerinin ilgasından yana olduğunu söylemesi, Gökalp hakkındaki bilinen yargılarımızla bağdaşmamaktadır. Türkçülük fikrinin en önemli fikir adamlarından olan Ziya Gökalp'in Arap harflerinin korunmasından yana olduğunu, Arap harflerini Rusya'daki Türklerle aramızda birleştirici bir kültür unsuru olarak telakki ettiğini biliyoruz' . Raporda verilen bu bilgilerin, kişisel takipleri de içerdiği bilindiğinden, Ziya Gökalp'in, bir dönemde, Arap harflerinin ilgasından yana bazı fikirleri ifadeye koyduğu düșünülebilir. Birbirleri ile devamlı fikir münazara ve münakașası içinde bulunan ilim ve fikir adamlarımızın zaman zaman fikir değiştirmelerinin, birbirlerinden etkilenmelerinin olağan bir süreç olduğu düșünüldüğünde, Ziya Gökalp'in bir dönemde Arap harflerine muhalif fikirler beyan etmesi mümkündür. Bundan başka İslam Derneği'nde Latin harflerinden yana konușma yapan Şair ve müderris Cenap Şahabeddin'in milli mücadele döneminde kuva-yı milliye ve Atatürk aleyhinde bulunduğunu bu dönem aydınların durumunu değerlendirmek açısından bilmek ve söylemek gerekir ${ }^{10}$.

${ }^{8}$ Celal Nuri 1914'te Tarih-i Tedenniyat-1 Osmaniye ve Mukadderat-i Tarihiye'sinde Latin harflerini net ifadelerle savunurken, 1926 'da Türk Inkılâbı adlı eserinde aynı netliği göstermemiştir. Daha sonra inkılâp sürecinde Latin alfabesinden yana net tavrına dönüş yapmıştır. Bkz. Faik Reşit Unat, aynı makale, s. 725. Bu bunalımlı devrin aydınlarında, zaman ve zeminin hızlı değișimi içinde gerek müspet, gerekse menfi etkileșimlerle bazı tedirginliklerin, endişelerin ortaya çıktığını, bu çerçevede fikirlerin değiştiğini çokça müşahede ederiz.

${ }^{9}$ Bilal Şimşir, Türk Yazı Devrimi, TTK, Ankara 1992, s.107.

${ }^{10}$ Cenap Şahabettin 22 Şubat 1922 tarihli yazısında Mustafa Kemal Paşa'ya şunları söylüyor. "...Paşa Hazretleri, siz bu memleketin bir kumandanısınız, ben de sahte bir tevazuu bir tarafa atarak diyeceğim ki, aynı memleketin bir edibiyim. Vatanımız için çare-i necatı (kurtuluş çaresini) siz kılıçta görüyorsunuz, halbuki bence vatanımız için imkânı-1 kıyam (ayaklanma ihtimali) silahta değil, kitapta; atește değil nurda, muharebede değil medeniyettedir” Bkz Tarık Zafer Tunaya, Türkiye'de Siyasal Partiler, C. II, İstanbul 1986. Hikmet Özdemir, Ulusun Direnişinde Üniversite'nin Rolü, Kocaeli Üniversitesi Yayınları. s.98-99. Ankara 2003. 
Kühlmann söz konusu raporunda, alfabe değişiminden yana olanların görüşlerini yazarak, bunlarla ilgili bir değerlendirme de yapmıştır. Değerlendirmesinde, Hüseyin Cahit'in alfabe değișikliği için öne sürdüğü gerekçelere katılmadığını yazmaktadır. Cehaletin ve okuma yazma oranının düşük olmasının asıl nedeni olarak okullaşmanın az olmasını, müfredat yetersizliğini, zorunlu eğitimin uygulanamamasını ve halkın büyük bir kısmının düşünsel tembelliğini görmektedir. Bu gibi tespitler eğitim sistemimizde bugün bile ciddiyetle tartışılması gereken konular olsa gerektir. Alman elçi böyle bir alfabe değişikliği teşebbüsünün kültürel kopuşa yol açabileceği ve Türkiye'nin İslam dünyasından kopabileceği endişesini açıkça ortaya koymaktadır. Bu konuda doğu zihniyetinde yazının, mezhebi milliyeti oluşturduğu realitesine de işaret etmektedir ${ }^{\mathrm{II}}$

Büyükelçi Kühlmann, bu konuda 27 Şubat 1917 tarihinde İstanbul'dan bir rapor daha göndermiş bu raporda da Latin alfabesi konusunu işlemiş ve raporunu şu yorumla noktalamıștır. "Eğitimle ilgili tecrübeye sahip oldukların düşünen Türk gazetecileri, alfabe değişikliği ile ilgili görüşlerinin doğru ve tam olarak anlaşılması halinde, Latin harflerinin faydalarının fazlasıyla takdir edilece ğini düşünüyorlar. Böyle bir yeniliğe karşı geniş çevrelerden gelecek tepkileri küçümsüyorlar. Bu yeniliğin gerek halk içinde gerekse devlet içinde kültürel ve siyasi açıdan meydana getireceği köklü sonuçlarını dikkate almıyorlar"'2.

Alfabe inkılâbımızdan yıllar önce ülkenin dil sorunlarının bu kadar geniş bir vukûfiyetle ve ilgiyle Alman diplomasi raporlarına geçmesi ve inkılâbı hazırlayan şartların adeta tarif edilmesi şayânı dikkattir. Alman diplomasi kaynaklarında bu tarihten 9 yıl sonra alfabe ile ilgili yenileşme konusu gündeme gelmeye başlamıştır. Aradaki boşluk, I. Dünya Harbi'nden sonra 1918 ile 1924 arasında resmi ilişkilerin askıda olmasından kaynaklanmıştır.

\section{b) Albreht Dürer Haus Örgütünün Faaliyetleri}

$\mathrm{Bu}$ dönemde Alman Büyükelçisi Nadonly ${ }^{13}$ Türk Harf İnkılabı ile ilgili 11 rapor yazmıştır. Bu raporların başlangıç tarihi Albrecht

"İstanbul Alman Büyükelçiliğinin Pera'dan yazdığı 8 Mart 1917 Tarih ve 164 nolu rapor, R. 13198, Türkei 134, Allgemeine Angelegenheiten der Türkei, vom 1. Januar 197 bis 31. Juli 1917, Bd.37, f. Bd. 38 .

12 İstanbul Alman Büyükelçisi Kühlmann'ın Pera'dan Kayzer Bethmann Hollweg'e yazdığı 27 Mart 1917 Tarih ve 135 nolu raporu, Alman Dışişleri Bakanlığı Siyasi Arşivi Berlin, Allgemeine Angelegenheiten der Türkei, Bd. 37, f. Bd.38, R. 13198, Türkei I34.

${ }^{13}$ Rudolf Nadolny 12 Temmuz 1873'te Doğu Prusya'da Gross-Stürlack'ta doğdu. Königsberg Üniversitesi'nde hukuk eğitimi aldı. 1902 yılında Alman Dışişleri Bakanlığında çalışmaya bașladı. 1903-1907 Almanya'nın Petersbug Konsolos yardımcısı, 1912-1914 Alman Dışişleri Bakanlığı'nda İran, Bosna ve Arnavutluk masası sorumlusu olarak görev yaptı. Birinci Dünya Savaşı'nın başlamasıyla birlikte subay olarak Alman Ordusunda görev yaptı. 1916'da Alman Dışişleri Bakanlığı tarafından elçi olarak Iran'a gönderildi ve 1917'ye kadar bu görevini sürdürdü. 1920-1924 Stockholm elçiliği, 1924-33 Türkiye Büyükelçiliği 
Dürer-Haus'un' ${ }^{14}$ Alman Dışişleri Bakanlığı'na yazdığı üç ayrı yazıyla aynı döneme tekabül etmektedir. Dürer Haus 8 Mart 1926'da yazdığı yazıda, Almanya'nın özellikle de Prusya Kültür Bakanlığı'nın içeride ve dışarıda destek verdiği ve desteklediği alfabe reformunun, Türkiye, Transkafkasya, Özbekistan ve Sovyetler Birliği'ne bağlı diğer Orta Asya ülkelerinde gündeme geldiğini bildiriyor ve "Sütterlin" adlı yazı tarzının" buralarda uygulanmaya konulması için Alman Hükümeti'nin yardımını talep ediyordu. $\mathrm{Bu}$ gerçekleştirildiği takdirde bu ülkelerde Alman Kültürünün yaygınlaşacağı ve gelişeceği öngörülmekteydi ${ }^{16}$. Elbette Türkiye'deki yazı reformunu 9 yıl öncesinden adeta öngören ve bu doğrultuda raporlar hazırlayan, bir teșkilatın bu konudaki çalışmalarının sadece Albrecht DürerHaus'un etkisiyle geliştiğini söylemek doğru olmaz. Ancak Albrecht DürerHaus faaliyetlerinin, Alman Dışişleri Teşkilatı'nın bu ülkelerdeki alfabe reformu çalışmalarını Alman menfaatleri doğrultusunda yönlendirmek açısından tetiklediğini söyleyebiliriz.

görevlerinde bulundu. 1933'de Moskova Büyükelçisi olarak atanmış ise de Hitler Almanyası'nın politikalarını benimsemediğinden 8 ay sonra bu görevini ve diplomasiyi bıraktı. 18 Mayıs 1953 'te vefat etti. Geniş bilgi için bkz. Rodolf Nadolny, Mein Beitrag. Erinnerungen eines Botschafters des Deutschen Reiches, (Yayınlayan Günter Wollstein), Köln 1985; Ahmet Özgiray, "Rudolf Nadolny'nin Hayatı", 19 Mayts ve Milli Mücadele'de Samsun Sempozyumu 20-22 Mayıs 1919, Bildiriler, Yay. Ondokuz Mayıs Üniversitesi Atatürk İlkeleri ve İnkılap Tarihi Araştırma ve Uygulama Merkezi, Samsun 2000.

${ }^{14}$ Albrecht Dürer 1471 yılında kuyumcu bir babanın üçüncü çocuğu olarak Nürnberg'de dünyaya geldi. Babasından kuyumcuyluk öğrendi. Ressam Michael Wolgemut'tan resim dersleri aldı. 1490-1495 yılları arasında mesleğiyle ilgili olarak Freiburg, Strassburg, Comlar, Basel ve Venediği gezdi. Venedik gezisi sonunda kendi atölyesini kurdu. 1505'deki İtalya gezisinde Bologna perspektifini öğrendi. 1520-21 yıllarında Hollanda'yı da gezen sanatçı 1528 'de Nürnberg'de öldü. Dürer, çalışmaları ile bir grafik sanatçısı olarak tarihe geçti. Geometri, sanat ve insan ilişkilendirerek tahlil eden üç ciltlik eseri çok meşhurdur. Bu gün Nürnberg'de kendi adını taşıyan bir cadde ve müzede eserleri sergilenmektedir. İşte Alman makamlarını harekete geçiren ve adını Albrecht Dürer 'den alan Albrecht Dürer Haus, Almanya'daki okullarda resim sanat alanlarında etkinlik gösteren bir sivil toplum örgütüdür. Geniș bilgi içn bkz. Mustafa Çolak, “İstanbul’daki Alman Büyükelçiliği Raporlarına Göre Mustafa Kemal ve Harf İnkılabı”, V. Uluslararası Atatürk Kongresi, Ankara, 8-12 Aralık 2003.

15 “Sütterlin” bir yazı biçimidir. Adını Ludwig Sütterlin'e izafeten almıştır. 1865-1917 yılları yaşayan Ludwig Sütterlin ünlü bir Alman Grafik sanatçısı olup, 1911 yılında Prusya Kültür Bakanlığı tarafından, yazının kolay öğrenilebilmesinin sağlanması ve Alman alfabesine estetik kazandırılması amacıyla görevlendirildi. Sanatçı "Sütterlin Yazı Biçimi”ni geliştirdi. Bu çalışma 1914 yılından itibaren önce Berlin'in bazı okullarında sonra Prusya'nın tamamında kullanıldı. Almanya 1934 yılında eğitimde birliği sağlamak amacıyla alfabe öğreniminde yeni bir metoda geçerek bu sistemi kaldırdı. Bu konuda geniş bilgi için bkz. Mustafa Çolak, "İstanbul'daki Alman Büyükelçiliği Raporlarına Göre Mustafa Kemal ve Harf İnkılabı".

${ }^{16}$ Albrecht Dürer-Haus'dan 8 Mayıs 1926 tarihinde Dışişleri Bakanlığına yazılan yazı, Alman Dışişleri Bakanlığı Siyasi Arşivi Berlin, Innere Verwaltung Türkei , Bd. I, Abılg. 6, R 78624 . 
Bu sivil toplum örgütünün harf inkılabından sonra, çalışmaları sırasında Alman hükümetinin ve resmi makamlarının gösterdiği yardıma ve yakın ilgiye teşekkür eden 8 Ekim 1928 tarihli yaz1 ${ }^{17}$, örgütün çalışmaları sonucundan memnun olduğunu göstermektedir. Bu konuda Alman Dişişleri Bakanlığı 10 Kasım 1928'de yayınevine yazdığı bir başka yazı da örgütün çalışmalarının sonucu olsa gerektir. Söz konusu yazıda Alman elçiliği, TBMM'nin Arap harfleri yerine Latin harflerini kabul ettiğini bildirilmiş ve bastıkları ders kitaplarını dağıtmak için uygun bir temsilci seçmeleri yayınevinden istemiştir. Ayrıca aynı yazıda İstanbul'daki Alman Elçiliği'nin yayınevine uygun bir temsilci bulabilecek bir durumda olduğu da

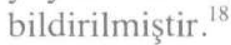

\section{c. Inkılap Öncesi ve Inkılap Sırasında Elçilik Raporları}

19 Eylül 1926'da büyükelçi Rudolf Nadolny imzalı bir rapor merkeze gönderilmiştir. Raporda bir yandan alfabe meselesinin hükümet tarafından rafa kaldırıldığı bildirilirken, diğer yandan Türkiye'de Roma kökenli dillerden bir dilin, örneğin Fransızca'nın öğrenilmesi ve transkripsiyonunun tercih edilmesi halinde, Almanların kültürel etki kazanma çabalarına zarar vereceği bildirilmektedir. Alman alfabesi veya transkripsiyonunun tabii olarak nazarı dikkate alınmayabileceğini söyleyen büyükelçi bu konuda çalıştığını şayet etkili olabilirse kısa süre içinde Macar transkripsiyonunun alınması için yönlendirme yapacağını bildirmektedir. Bu müdahaleyi açıktan yapamayacağını belirten elçi açıktan yapılan müdahalenin ters tepeceğini söyleyerek inkılapçıların milli hassasiyetlerine de dikkat çekmiştir. ${ }^{19}$

$\mathrm{Bu}$ raporda büyükelçi açıkça, kültürel nüfuz sağlamak amacıyla çalıştığını beyan ederken, Alman alfabesinin doğrudan etkisinin olamayacağını öngörmektedir. I. Dünya savaşından mağlup çıkan ve galip devletlerin baskı ve gözetiminde siyaset üretmeye çalışan Almanya'nın bu dönemde Türkiye'deki etkisinin sınırlı olacağı bilinmektedir. Raporda Fransız etkisinin ve Latin esaslı dillerden Fransızca'nın öne çıkması Alman çıkarlarına bir tehdit olarak yorumlanmıştır. Almanya'nın doğrudan etkisi olamayacaksa, hiç olmazsa Almanya ile kültürel yakınlı̆̆ı olan Macaristan etkisi tercih edilmektedir.

Büyükelçi 1 Şubat 1927 'de hazırladığı raporda siyasi olmayan, ilim çevresinden bilgi edinme ihtiyacı duyduğunu, bunun için Avusturyalı Türkolog Dr. Witteck'ten değerlendirme yapmasını istediğini bildirmektedir; Dr. Witteck, Latin alfabesinin kabulünün büyük zorluklara yol açacağının

${ }_{17}$ Dışişleri Bakanlığı Siyasi Arşivi, 3 Ekim 1928, 7286, R. 78624.

18 Gülnihal Bozkurt "Türk Harf Devrimi'nin Alman Arșiv Belgeleri’nde Değerlendirilmesi" XII. Türk Tarih Kongresi, Kongreye Sunulan Bildiriler,C IV .., s 1360 TTK Ankara 1999.

${ }^{19}$ Alman Büyükelçisi Nadolny’nin Therapia'dan 19 Eylül 1926 tarihinde Dışş̧leri Bakanlığına gönderdiği rapor, Dışişleri Bakanlığı Siyasi Arşivi Berlin, Türkei, Innere Verwaltung, R. 78624. 
görüldüğünü bu nedenle de istenmediğini düşünmektedir. Büyükelçi görüşünü aldığı ilim adamına rağmen kendi kanaatini aynen şu cümlelerle ifade etmiştir; "Ama ben Latin alfabesine muhalif gurubun ileri gelenlerinden Prof. Fuad Bey ve çevresinin desteklediği görüșlerin Türk hükümeti üzerine bir etkisi olacağına inanmıyorum. Ankara, zamanı gelince masraf ve zorluklardan kaçınmayarak tıpkı diğer reformlarda olduğu gibi bütün problemleri aşacaktır"20. Bu ifadeler göstermektedir ki, Alman Diplomasisi yaklaşık 2 yıl öncesinden harf inkılâbını tam olarak kestirmiş ve öngörmüştür. Bu durum onların siyasi mahfillerin nabzını da çok iyi tutuğunu göstermektedir.

17 Şubat 1927 'de yazılan raporda Nadonly, Kurul'un çalıșmalarını sürdürdügünü belirtmiş ve Hükümet'in Edebiyat Fakültesi'nden bilirkişi olarak Ragıp Hulusi Bey'i çağırdığını ve bilirkişinin kesinlikle bu yeniliğin karşısında olduğunu yazmıştır. ${ }^{21}$ Bir başka Alman görevli Südhof ise 29 Nisan tarihli raporda ise projenin gerçekleşmeyecek gibi göründügünü bildirmiştir. $^{22}$

Büyükelçi 31 Ağustos 1928 tarihli raporunda, Latin alfabesine geçiş için oluşturulan komisyondan kaynaklanan bir haberi merkezine ulaştırmıştır. Bu komisyonun bir üyesinin büyükelçiye bir iki Macar ve Latince harf haricinde, Alman harflerin değişim için tercih edilebileceğini, Fransız alfabesinin ise uygun olmadığ söylemektedir ${ }^{23}$. Bu raporda göstermektedir ki, Almanlar bu değişimden kültürel etkinlik adına çok şey beklemektedir.

Harf inkılâbının fiili olarak oluştuğu ve resmi olarak gerçekleștirilmesi aşamasına yaklaşıldığı sıralarda elçilik raporlarında bununla ilgili değerlendirmeler tafsilatlı olarak yer almıştır. Bu değerlendirmelerden biri de Büyükelçi vekili Aschmann imzasını taşımaktadır. 29 harfli yeni Türk alfabesi örneği gazetede yayınlanmıştır. Yayınlanan bu alfabeyi inceleyen Almanlar, yeni Türk alfabesini Almanca transkripsiyona uygun bulmaktadır. Çoğu harfler ve özellikle vokaller Almanca yazım için uygundur ve bu Almanya'nın menfaatinedir. Bu yenilik Türk basınında çok önemli kültürel

20 Alman Büyükelçisi Nadolny'nin Istanbul'dan 1 Şubat 1927 tarihinde Dışişleri Bakanlığına gönderdiği rapor, Dışişleri Bakanlığı Siyasi Arşivi Berlin, Türkei, Innere Verwaltung, R. 78624. J.Nr.. A 208- Fuat Köprülü nün muhalif görüşleri hakkında bkz. "Harf Meselesi”, Milli Mecmua, 1 Kânunuevvel 1926, C. VII, sayı 75, s.397- Bilal Şimşir, Türk Yazı Devrimi, s.76

${ }^{21}$ Alman Büyükelçisi Nadolny'nin İstanbul'dan 17 Şubat 1927 tarihinde Dışişleri Bakanlığına gönderdiği rapor, Dışişleri Bakanlığı Siyasi Arşivi Berlin, Türkei, Innere Verwaltung, R. 78624 .

${ }^{22}$ Alman Büyükelçiliğinden Südhof'un 29 Nisan 1927 tarihinde gönderdiği rapor, Dışişleri Bakanlığı Siyasi Arşivi Berlin, Türkei, Innere Verwaltung, R. 78624.

${ }^{23}$ Alman Büyükelçisi Nadolny'nin Therapia'dan 31 Temmuz 1928 tarihinde Dışişleri Bakanlığına gönderdiği rapor, Dıșişleri Bakanlığı Siyasi Arşivi Berlin. Türkei, Innere Verwaltung, R. 78624. 
bir olay olarak kutlanmaktadır. Yeni Türk alfabesinin, Avrupa dillerine yazım olarak uyumu, Türkiye'nin Avrupa'ya kültürel ve ekonomik açıdan bağlanmasını kesinleştirmiştir. Komisyon Arap ve Farsça kelimeleri Türkçe'den temizlemeye çalışmaktadır. Gazi yüksek enerjisiyle bizzat bu problemle uğraşmaktadır. İlgili bakan ve milletvekillerini denetlemekte ve alfabeden beklenen yararları halka açık konuşmalarda izah etmektedir. Bu yenilik onun şahsi gayretiyle gerçekleşmiştir. Latin alfabesinin kabulü Türkiye'de yaşayan yabancılar için önemli bir kolaylıktır. Türkiye'deki batılı yabancı iş adamları için eski Türk alfabesinin ve rakamlarının kaldırılmasıyla, dilin öğrenimi çok kolaylaşmıștır. Bu yeniliğin meydana getireceği maliyet, (baskı makinelerinin değişmesi, bütün kitaplarının yeniden basımı vs.) düşünen Türkleri endişelendiriyor. Ancak eğitim görmüş kitlelerdeki olumlu etkiler gözden uzak tutulamaz ve her şeye rağmen, Latin alfabesinin kabulü memleketin modernleşmesi yolunda çok önemli bir adımdır. Türk gazeteleri, yeni alfabenin kültürel ve ekonomik yönden Avrupa'ya ve Avrupalılık ruhuna doğru çok önemli bir adım olduğunu yazıyorlar. Alfabe değişimi dini alanda da önemli bir tesir yapacaktır. Türk Hükümeti'nin Kuranı yeni harflerle bastırmaya niyetlendiğini duyuyoruz. Böylelikle Müslümanlık geri kalmışlıktan kurtarılarak reform edilmiş bir Müslümanlığa sahip olunacak ve İslam dini geri kalmış Asya toplumlarına ait bir din olmaktan çıkartılarak ıslah edilecektir. Mustafa Kemal dini alanda doğacak boşluğu Hıristiyan misyonerlerin alabileceğini ve bu durumun dış tesirleri doğurabileceğini hesap ederek bir takım tedbirler almaktadır. Arap kültüründen sıyrılarak Türk Milliyetçiliği fikri çerçevesinde benliğini bulan bir anlayış hızla yayılmaktadır ${ }^{24}$.

Bilindiği gibi, resmî olarak 1 Kasımda gerçekleşen inkılap, yapılan hazırlıklar doğrultusunda gayri resmî olarak yaz aylarında gerçekleşmiştir. Yukarıda ifadeye konan rapor bu durumun Alman diplomasisi tarafından açıkça bilindiğini göstermektedir. Nitekim 1928'in Ağustos'unun son günü kaleme alınan bu rapor inkılabın gayri resmî gerçekleştiğini haber vermektedir. 1928 yılının Mayıs ayında çıkarılan "beynelmilel rakam"ın kullanılması hakkındaki kanun 1 Haziran 1928 tarihi itibariyle yürürlüğe sokuldu. Bu kanunun meclisteki görüşmeleri sırasında bir çok hatip harflerin de değiştirilmesi yolunda nutuklar söyledi. Millî Eğitim Bakanlığı'nda teşekkül ettirilen komisyonun Latin esasından alınacak harflerin Türkçe'ye uygulanabilirliğini gösteren çalışmalar olumlu netice verince, ikinci aşamaya geçildi. Bakanlık alfabe çalışmasını tamamlamak üzere 26 Haziran 1928'de önce 9 kişiden oluşan, sonrasında beș üye ilaveyle 14 'e çıkarılan "alfabe encümeni"ni kurdu. 1928 yılı Ağustos'unun 9'unu 10'una bağlayan Perşembe gecesi Gülhane Parkı'nda Mustafa Kemal Atatürk Harf İnkılabı'nın başladığını müjdeleyen ünlü nutkunu söyledi. 11 Ağustos

${ }^{24}$ Aschmann'ın 31 Ağustos 1928'de gönderdiği yazı, Bundesarchiv-Berlin Handel im allgemeinen Handelgesetzgebung, Türkei, R. 901, Nr. 54289; aynı belge Almanya Dışişleri Bakanlığı Siyasi Arşivin'de de bulunmaktadır. N. A 1612/28. R. 78624. 
1928 'de Dolmabahçe sarayında yeni Türk harfleri üzerine ilk tatbiki ders açıldı. 25 Ağustos $1928^{\prime}$ de yine Dolmabahçe sarayına çağırılan milletvekilleri, edipler, gazeteciler, bilginler, bir kongre halinde toplandılar. Atatürk'ün davetiyle gerçekleşen bu toplantı 25, 27 ve 29 Ağustos tarihlerinde üç gün sürdü. ${ }^{25} \mathrm{Bu}$ toplantıya mebusların niçin ve nasıl gelecekleri davetiyede belirtilmişti. Yeni Türk harflerini öğrenmiş olarak teşrifleri isteniyordu. Gelen mebuslar sadece konferans dinlemeyecekler aynı zamanda bir çeşit sınava tabii tutulacaklardı. Bu nedenle olacak Londra'da çıkan 31 Ağustos 1928 tarihli The Times gazetesi, bu haberi "mebuslar okula gidiyor" başlığı altında vermiştir ${ }^{26}$.

Yukarıda bahsedilen 31 Ağustos tarihli raporun, yukarıda özetlediğimiz alfabe inkılâbı sürecindeki Türkiye olaylarını ihtiva ettiği görülmektedir. Ancak burada ilgi çekici bir yorum ve beklentiden ayrıca bahsetmek gerekir. Büyükelçi vekili harf değişimini ve Kuranın yeni harflerle basımını İslam'ı reforme edecek ve geliştirecek bir araç olarak düşünmektedir. Dinin geri bırakan emir ve kaidelerinin eski yazının tarihe gömülmesi ile unutulacağını, yeni ve ileri bir dini anlayışın gelişeceğini öngörmektedir. Bizce yanlış olan bu yorumun iki temel nedeni vardır. Büyükelçi, İslam dininin özelliklerini tanımadığı için, Hristiyan dininin geçirdiği reform sürecinin, İslam içinde geçerli olabileceğini düşünmektedir. Ayrıca, din ve dinin gereği sayılan ve belki de yanlışlıkların büyük kısmını içinde barındıran geleneklerin alfabe ile tarihe karışacağını sanmaktadır. Bu nedenle alfabe değişikliği dinî bir terk ediş olarak yorumlanmıştır. Bu öngörüler tarihen ve ilmen mümkün değildir ve gerçekleşmemiştir ${ }^{27}$.

\section{d. Inkilâp Sonrası Elçilik Raporları}

Harf İnkılâbından hemen sonra 5 Kasım 1928'de Nadonly uzun bir rapor yazarak, harf inkılâbının Türkiye'deki tarihini ve bu inkılâbın Türk Alman ilişkilerindeki anlam ve önemini açıklayan bir raporu merkezine

${ }^{25}$ M. Şakir Ülkütaşır, "Harf İnkılabı ve Atatürk", Türk Kültürü, S.85, Y.VIII, sf. 94 vd. Ayrıca bu dönemdeki olayların kronolojik lstesi için bkz. Gotthard Jaeschke. Türk Inkılâbı Tarihi Kronolojisi 29. 10. 1923- 1.1. 1930, İkinci Cilt, Türkçeye çeviren: Niyazi Recep Aksu, IÜEF Türk İnkılâbı Tarihi Enstitüsü Araştırmalarından IV, İstanbul 1941.

${ }^{26}$ Şimşir, age s.174-175.

${ }^{27}$ Sosyal ve kültürel değişimlerden ve özellikle din konusundaki değişme ve gelişmelerin son derece güç ve yavaş olduğu sosyal bilimlerle uğraşanların malumudur. Bu süreç ülkemiz içinde geçerli bir süreçtir ve köklü bir zihniyet değişimi gerektirmektedir. Her ne kadar çağın teknolojisi ve araçları ile bu değişim ülkemizde geçmişe nazaran oldukça hızlanmış ise de, bu konuda da bir zihniyet devriminin başarılmış olduğu söylenemez. Yaşar Nuri Öztürk, Hüseyin Atay, Hasan Elik gibi bilim adamı hüviyetindeki İslam'ın çağdaş yorumcularının halihazırda büyük bir kesimin tepkisini çektiği hatırlanmalıdır. Bu kișilerin geleneksel bilgileri sorgulamaları ve dinin ana kaynaklarına giderek, öze dönüşle bir değişimi talep etmeleri bile, dinde reform ve dini değiştirerek dejenere etme iddialarına maruz kalmalan için yetmektedir. Din Sosyolojisi ve Psikolojisi ile ilgilenenler bu durumu tüm açıklığı ile teşhis etmekte bu tür değişimlerin güçlüğünü bilmektedirler. 
göndermiştir. Buna göre Tanzimat'a kadar uzanan bir geçmişe uzanan alfabe sorununa sahip Türkiye bu önemli reformu ansızın ve hiç beklenmedik bir anda gerçekleștirmiştir. Alfabe arayışındaki en önemli motivasyon Bolșevik ihtilâli olmuştur. Bu hareketle Carlık Rusyası'nın baskısından kurtulan Türkler, gelişmelerini sağlamak ve batılılaşma hedeflerini gerçekleştirmek için dillerine uygun alfabeyi hayata geçirme çalışmalarına başlamışlardır. Azerbaycan bu yolda Türkiye ile beraber hareket etmek istemiş ve daha 1920 yılında Mustafa Kemal'le görüşmüş ve Latin harflerine dayalı bir alfabe değişikliği konusunda anlaşmıştır. Ancak, Mustafa Kemal'in Millî Mücadele ortamında yeni bir devletin teșekkülünün yanında daha öncelikli reformları vardır ve I. ve II. Mecliste böyle bir reformun başarılmasını sağlayacak ortam mevcut değildir. Nitekim 1923 İzmir İktisat Kongresi'nde alfabe değişikliği ile ilgili girişimler kabul görmemiştir. İçteki ve diştaki dengeleri gözeten Mustafa Kemal, Ocak 1928'de Türkmenistan ve Özbekistan'ın Latin harflerine geçmesiyle birlikte uygun zamanın geldiğini düşünerek harekete geçmiştir.

İnkılâbın bilinen safahatını raporunda geniş geniş anlatan Nadonly, yeni Türk alfabesinin, Latin alfabesini kullanan farklı Avrupa ülkelerinin değişik yazım şekillerinin incelenerek ve dikkate alınarak hazırlandığını söylemektedir. Alfabenin yazımı konusunda Fransızların önerileri kabul görmemiş buna mukabil, Almanca'ya yakın olan Doğu Avrupa ülkelerinin yazım şekli alınmıştı ve kelimeler konuşulduğu gibi yazılmaktaydı.. Sesli harflerin tamamı Almanca'dan alınmış fakat sessiz harfleri Türk dilinin ihtiyaçları belirlemişti, Nadonly, alfabe çalışmalarının, dilin sadeleştirilmesi yani Arapça ve Farsça kelimelerden arındırılması çalışmalarıyla paralel yürütüldüğünü belirtmektedir.

Raporda, özellikle Alfabe İnkılâbı'nda Atatürk'ün inanılması güç performansı tasvir edilmiștir. Burada Atatürk, Rusya'yı batılılaştıran ve Rusya'nın kaderini değiştiren Rus çarı Petro'ya benzetilmekte ve şöyle tasvir edilmektedir.

“...Tabiiki gerek ilim adamlarından gerekse din adamlarından oldukça sert muhalefet yapanların sayısı az değil. Alınan tedbirleri eleştiriyorlar ve gerçekte halkın buna karşı olduğunu iddia ediyorlar. Fakat Mustafa Kemal'in şahsiyeti ve inisiyatifi yapılan yeniliklerde şüphesiz öncü rol oynamaktadır. O, Peter der Grosse gibi, Asyalı halkını kamçıyla Avrupalılaştırmaya götürmektedir. Yapacağı reformlara karar verdiğinde bütün enerjisiyle uygulamaya koyulmaktadır. O bir şeye karar verdimi, bütün varlığı ve gücüyle onu gerçekleştirmek için çalışıyor. Onun yapmakta olduğu yeniliklere kimse, karşı koymaya cesaret edemez ve edememiştir. Önceden alfabe değiş̧ikliğine karşı çıkanlar Mustafa Kemal'in alfabe değişikliğine taraftar olduğunu görünce, seslerini kesmişlerdir. Nitekim Gazi'nin uygulamaya koyduğu yeni alfabeye karşı muhalefet hiçbir ses çıkaramamıştır. 
Ekonomik gidişatın uzun süredir kötü olması nedeniyle onun bütün reformları kötü bir zemine çarpıyor. Bundan dolayı halkın reformları genelde isteyerek kabul etmediği de şüphesizdir."

Nadolny bu tespitlerden sonra Almanya açısından bir durum değerlendirmesi yaparak şöyle demektedir: Bence Almanlar yönünden alınan tedbirlere memnun olunmalıdır. Yeniliklerle Türklerin Fransız kültür çevresinden uzaklaştıkları ve Almanya tarafından etkili olan Doğu Avrupa çevresine girdiği görülmektedir. Bu gerçek bizim açımızdan menfaat sağlayabilir ve aynı zamanda ekonomik kazanç temin edebilir. Kabul edilmelidir ki kılık kıyafet, Avrupa kanunlarının kabulü ve alfabe reformu Türkiye'nin batılılaşması yönündeki başarılı adımlardır. Yeni alfabenin kabulünün özellikle kültürel ve tarihi bir öneme sahip bir olay olarak ancak birinci sınıf devlet adamlarının başarabileceği bir iştir. ${ }^{28}$

Nadolny'nin bu raporundaki bilgilerde gerçekten son derece ilgi çekicidir. Alfabe reformunun daha devlet kurulmadan Mustafa Kemal tarafından düşünüldügüünü, hatta 1920 'de bu konuda Azerbaycanlılarla görüştüğünü, daha sonrada Türk dünyasındaki gelişmelere göre reformun zamanlamasını belirlediğini söylemesi gerçekten önemli ve değerli bilgilerdir. Raporda Mustafa Kemal'in inkılâpçı ve kararlı kişiliğinin tarif edilmesi ve bu tariflerde başarılara işaret edilirken onun kişiliğinden övgüyle söz edilmesi, onun yapmak istediklerinin Almanlarca tam anlamıla anlaşıldığını göstermektedir. Onun muasır medeniyet seviyesini hedef gösterdiği halkına yol açmak için yaptığ çalışmaları ve bu yoldaki kararlılığı çok açık ve net olarak ortaya konmuştur.

31 Aralık 1928 tarihli bir başka raporda ise, Latin harflerinin kabulüne dair kanunun tüm güçle uygulandı̆̆ı, 1 Aralık'tan itibaren uygulanacak yüksek para cezalarının etkisiyle bütün kapı levhalarının ve reklam tabelalarının Latin harflerine çevrildiği, aynı kanunun 4. maddesi gereği 1 Aralık'tan itibaren gazetelerin Latin harfleri ile çıktığı bildirilmektedir. Ocaktan itibaren tüm kitaplar yeni harflerle basılacak, mektup zarflarının üzeri yeni yazı ile yazılacak, memurlar arasında Arap harflerinin kullanımı asgariye indirilecektir. Memurlar Latin harfleri ile ilgili kurs ve imtihanlara sokulacaklar ve halkın en kısa zamanda Latin harflerini öğrenebilmesi için Halk Okulları kurulacaktır. Bu okullarda verilecek kurslar Arap harflerini bilenler için iki, hiç okuma yazma bilmeyenler için dört ay sürecek, 16 yaşından küçüklerle, 45 yaşından büyükler bu kurslardan muaf

28 Bkz. İstanbul Alman Büyükelçiliğinden 5 Kasım 1928 tarihinde yazılan rapor, Alman Dışişleri Bakanlığı Siyasi Arşivi Berlin, Innere Verwaltung Türkei, Bd. I, R 78624. 
tutulacaklardır. Büyükelçi, bu kadar kısa sürede, bu kadar büyük başarının ve ilerlemenin kaydedilmesini gerçekten çok dikkat çekici bulmaktadır. ${ }^{29}$

Alman elçilik raporlarında harf inkılâbının akisleri, inkılâbın sıcak günleri sonrasında da devam etmiştir. 4 Nisan 1929 tarihli ve Ankara mahreçli büyükelçi raporu "Türk Dil ve Yazı Reformu başlığı altında verilmiştir. Raporda, Latin alfabesinin kabulünde ana gerekçenin okuma yazma oranının düşük olduğu gerçeği hatırlatılmakta, Türk hükümetinin bu konudaki mücadelesinin kararlılıkla devam ettiği bildirilmektedir. Yeni alfabenin öğrenilmesi yolunda halkın ilk zamandaki heyecanını kaybettiği görüldüğü için, yetkililer okula gitmekle yükümlü olanların kısmen taltiflerle kısmen de ceza tehdidiyle motive edilmesinin gerekliliğine inanmaktadır ${ }^{30}$.

Yine 10 Haziran 1929 tarihli "Türk Yazı ve Dil reformları" başlıklı bir başka raporda, bundan böyle Arap alfabesinde yazılmış hiçbir yazının resmi makamlarca kabul edilmeyeceği, Mısır, Suriye gibi diğer ülkelerden gelen posta ve telgrafların da geri gönderileceği, Arap harfli başlıklı mektupların alınmasından kaçınılacağı bildiriliyor. Ayrıca bu uygulamalarla Latin alfabesinin kabulünün milli çabaların güçlenmesini sağladığı ve her şeyin Türkçeleştiği yorumu yapılıyor ${ }^{31}$.

"Türkiye'deki Kültürel İnşa" başlıklı bir başka rapor da ise dikkat çeken bazı ifadeler yer almaktadır;

Türkiye son yıllarda Mustafa Kemal ve çevresinin bilinçli olarak oluşturduğu hatta, ülkenin kültürel inşasına başlandı. Bunun sonuçlart bugünden itibaren başkent Ankara'dan başlayarak bütün Anadolu merkezlerine yayılacak. Türkiye'nin kültürel çıkışı için Latin harflerinin kabulü temel yenilik olarak görülmelidir. Bu yenilik yepyeni bir neslin el ele büyümesine ve başartsına vesile olacak. Cehalete karşı mücadele devam edecek.

Bunun yanında Gazinin çabaları alfabe ile sınırlı değildir. Türk dilini Türkçe olmayan kelimelerden temizlemek amacındadır. Türkçülüğün araștırılması alanında teşvik ve desteklere önem vernektedir. Bugün rejimin anahtarı konumunda olan Milli mücadeleyi yapan askerlerin ve entelektüellerin koruduğu Gazi, büyümekte olan gençliğin temel ve milli eğitimleri üzerine temel hedefini Türkiye'nin batılılaştırılması olarak

29 Alman Büyứkelçisi Nadolny’nin Therapia'dan 31 Aralık 1928 tarihinde Dışişleri Bakanlığına gönderdiği rapor, Dışişleri Bakanlığı Siyasi Arşivi Berlin, Türkei, Innere Verwaltung, R. 78624 .

3) Nadolny'nin İstanbul'dan 4 Nisan 1929 tarihinde gönderdiği yazısı, "Die türkische Schrift und Sprachreform", Türkei Reformen für die Europäisierung der Türkei, Ankara; 536, Alman Dışişleri Bakanlığı Siyasi Arşivi Berlin.

${ }^{31}$ Nadolny'nin İstanbul'dan 10 Haziran 1929 tarihinde gönderdiği yazısı, "Fortführung der türkischen Schrift- und Sprachreformen", Türkei Reformen für die Europäisierung der Türkei, Ankara;536, Alman Dışişleri Bakanlığı Siyasi Arşivi Berlin. 
belirledi. Fakat bu yöndeki ana engel uzman ve yeterli derecede eğitim elemanının bulunmayışıdır. Bu engel hükümet tarafindan gösterilen bütün çabalara rağmen hala aşılamadı",32.

Bu raporda Atatürk'ün batılılaşma yolundaki hedefi belirtilirken, devletin yetişmiş eleman sıkıntısını dile getirmekte ve bu sorunun hükümetin en önemli sıkıntısı olduğu bildirilmektedir. Gerçekten de Cumhuriyetimizin kuruluşu süreci ve sonrasında yetişmiş insan sıkıntısı çekilmesi, tarihimizin acı gerçeklerindendir. Zaten yetişmiş insanı az olan ülkenin elindeki yetişmiş insan potansiyelini I. Dünya Savaşı'nda ve Kurtuluş Savaşı'nda yitirmiş olması gerçeği, yeni Cumhuriyet idaresinin en büyük sorunu olmuştur.

\section{Alman Basınında Türk Alfabe Ínkılabı}

Alman diplomasisi kadar olmasa ve hatta oldukça az sayıda da olsa bile, Alman basını da harf inkılâbını izlemiş ve yorumlamıştır. Bunlar özellikle harf inkılâbının hemen sonrasında olmuştur. "Türkiye Latince Yazıyor" başlıklı bir gazete haberi inkılâbı haber vermekte ve harfleri değiştiren kanunun çerçevesini izah etmektedir. Basının yeni yazıyı Türk İnkılâbının en önemli eseri olarak yorumladığı da özellikle belirtilmektedir ${ }^{33}$.

Yine bu dönemde, 1 Kasım 1928 yılında Prusya Milli Kütüphanesinin Oriyantalistik Bölümünün Müdürü Profesör Dr. Gotthold Weil'in geniş bir değerlendirme yazısı basında yer almıştır. "Türk Dilinin İlgası, Yeni Sözlük, Dil Komisyonunun Görevi” başlıklı makalede ilgi çekici bilgi ve yorumlar vardır. Bunlar aynen şu ifadelerle belirtilmektedir.

"Hali hazır bildirildiğine göre, Ankara hükümeti oldukça girift, nakış gibi işlemek zorunda olduğu zor bir işe kalkışıyor. Türk-Arap yazısını kaldırmak ve Latin alfabesini almak istiyor. Yaklaşı 1000 yıl önce Türkler dillerine uymamasına rağmen dini metinlerinin bu alfabe ile yazılı olmast nedeniyle Arap alfabesini kabul etmişlerdi Şimdi o tekrar ilga edilir ve Hiristiyan Avrupa'da genel olarak yaygin olan, geleneksel Romen harfleri kabul edilirse, Türk milli devleti ve Íslam dünyası arasinda yeni bir set oluşacak. Fakat şu bir gerçek ki, Arap harfleri Türkçe sesleri vermeye uygun değil. Okuma ve ögreniminde zorluklar oluşturuyor. Yine de Türkiye'de okuma ve yazma bilmeyenlerin sayısının yüksek olmasını yalnız bununla açıklamak kesinlikle doğru değil ama sadece yüksek okul mezunu Türklerin ana dillerini tam olarak bildikleri bir gerçek olarak ortada. Işte bu gerçek ve ülkenin batılılaştırılmasında mesafe alma arzusu, Türk önderini harekete geçirdi. Bazı karşı koymalara rağmen, Latin alfabesinin kabulü için teklifler çalışmalar yapmak ïzere bir dil komisyonu oluşturdu.

32 "Kulturelle Aufbau in der Türkei", Türkei Reformen für die Europäisierung der Türkei, ANKARA; 536. Alman Dışişleri Bakanlığı Siyasi Arşivi Berlin.

${ }^{33}$ "Die Türkei schreibt latenisch, Nachrichtendienst der", Vossischen Zeitung, Angora, 2 Kasım. 
Bugüne kadar kullanılan yazı da bütün kelimeler özellikle yabancı olan ilk anlamına uygun. Arapça'dan gelen ünsüzlerle yazılan Arapça kelimeler çok fazla ve bunlar sadece eğitimli kişiler tarafindan tam olarak okunabiliyor. Bu özellikleriyle Arap alfabesi yazım sekli önerilen Latin alfabesi ile çelişmektedir. Ayrıca Türkiye'de her eyalet ve yerleşim merkezi bizdeki gibi çeşitli şivelerde konușmaktadır. Bu nedenle "konuştuğun gibi yaz" temel düsturunun uygulanabilmesi için hangi șivenin yazım kılavuzu olarak uygulanacağına karar verilecek. Bu kararda İstanbul Türkçesi tercih edilecek. Bu takdirde Küçük Asya'nın Türkleri yani bütün Türklerin onda dokuzu, gelecekte doğru yazabilmek için Istanbul diyalektiğini öğrenmek zorundalar. Yeni Latin alfabesinin kullanımı da büyük zorluk çıkaracak. Bu zorlukları en aza indirmek, dilin gelişimi için temel esasları oluşturmak, resmi olarak dildeki Arapça kelimeleri belirlemek ve büyük ölçüde ortak yazım tesis edebilmek için parlamento tarafindan tanınan dil komisyonu 40 000 ila 60000 kelimeyi kapsayan yeni bir sözlük yaymlayacak. Bu sözlükte bütün Türkçe ve Arapça kelimelerin resmi olarak belirlenen yeni bir yazım şekli bulunacak. Doğru yazmak isteyen her kimse bu kalın sözlüksüz Türkiye Cumhuriyetinde yaşayamayacak.

Bütün bu zorluklara rağmen yeni alfabe kısa süre içerisinde yürürlüğe girecek. Bütün eski yazılar sokak tabelalarından, kitap ve gazetelerden kaybolacak. Bundan sonra bütün ilkokul öğrencileri 29 kolay harfi öğrenmek zorunda olduğu için, okuma yazma bilmeyenlerin sayısı azalacak. Fakat basklları bulunan klasikler ve eski zamanlardan kalma Türk eserleri hayatiyetini yitirecek. Kendi edebiyatını öğrenmek isteyen Türkler, Arap dilini ve kaldırılan Türk-Arap harflerini yabancı dil gibi ögrenmek zorunda kalacaklar. Bu nedenle gelecekte Türkçe için iki ayrı sözlük olacak. Eski Türk edebiyatını yeni alfabeye kazandırmak çok büyük bir maliyeti gerektirmektedir. Türkiye'nin hassas yöneticileri bu reformun, kendi milli geçmişlerine ve kültürlerine karşı genel bir yabancılașmaya neden olmasından dolayı çok act çekecekler. Fakat buna rağmen kararlarından dönmeyecekler ${ }^{34}$

Görüldüğü üzere yazıda alfabe değişiminin nedenleri ve zorlukları tahlil edilmiştir Bu gazete makalesinde Türk Dil İnkılâbı'nın ana sebepleriyle özetlendiğini ve akademik bir üslupla tahlil edildiğini görüyoruz. Gerekçelerde mahzurlarda açıkça yazılmış, dilin gerek yazımında gerekse diyalektiğindeki kuralları oluşturmak için yapılan çalışmalar, büyük bir vukufiyetle ortaya koyulmuştur. Professor Dr. Gotthold Weil, yazısını ilgi çekici bir yorumla bitirmiştir. Zorlukların İnkılâpçılar tarafından bilindiğini fakat onların yollarından asla dönmeyecekleri ifade edilerek Mustafa Kemal ve arkadaşlarının kararlılıklarına dikkat çekilmiştir.

${ }^{34}$ Gotthold Weil. “Die Abschaffung der türkischen Schrift. Das neue Wörterbuch. Aufgaben der Sprachkommision”, Berliner Tageblatt, 1 Kasım 1928. 
Alman basınında 2 Kasım 1928 tarihli "Türkiye'de Latin Alfabesi" başlıklı bir haber de dikkati çekmektedir. Millet Meclisi'nin Atatürk'ün nutkuyla açıldı̆̆ını, bu konuşmadan sonra Kâzım Paşa'nın tekrar Millet Meclisi Başkanlığı'na seçildiğini, daha sonra Latin -Türk alfabesinin kabulü üzerine müzakereye geçildiğini ve yasanın oy birliği ile kabul edildiğini haber veren gazete, kanunun içeriğini de ayrıca açıklamaktadır ${ }^{35}$.

Yukarıda örneğini sunduğumuz Alman basınındaki çok az sayıdaki haber ve yorumların Türk basınındaki haber ve yorumlardan kaynaklandığını ve Türk basınındaki haberlerin oldukça özet haline getirilerek Alman basınında sunulduğunu görmekteyiz.

\section{Tïrk-Alman Dostluk Derneği}

Türk Alman Dostluk Derneği, Kasım/Aralık 1928 bülteninde, Karl Klinghardt imzasıyla geniş bir değerlendirme yazısı yayınlamıştır.

Latin Alfabesinin kabulünü Türk medenileşme programı içerisinde en önemli adım olarak yorumlayan yazar, inkılâbı artısı ve eksisiyle değerlendirmeye çalışmış ve olumlulukların daha ağır bastığı sonucuna varmıştır. Başarıdaki Atatürk faktörünü açıkça belirlemiştir. Makalede şu satırlar dikkat çekmektedir;

"Latin Alfabesi Türk medenileşme programı içerisinde en önemli adımdır. Arap alfabesinin yerine Latin alfabesinin kabulï her şeyden önce mevcut gelene ğe yeni bir ret anlamına gelmektedir. Hatta bu gelecek için de bir ret olabilir. Kemalist reformlar başarılı olamasa da Arap harfleri ile birlikte unutulan bilgilerinin halk tarafindan bir daha kazanılması söz konusu olmayacaktır. Diğer taraftan Latin harfleri ile kolaylaştırılmış yazı biçiminin medeniyet ve ekonomik ilerleme anlamında avantajları çok açıktır. Dolayıstyla bu son reform yeni Türk modernleşme programının mantıklı bir neticesidir. Böylece Türkler Batı ïlkeleri ile sağlıklı ilişkiler kurmak, Batılılar da Türkiye ile ekonomik ve kültürel ilişkiler tesisi etmek yolunda uygun bir vasat elde ettiler. Reformcular yeni yazı inkılabtyla dezavantajlart tamamen bertaraf ederek avantaja çevirdiler.

Türk dili için Arap alfabesinin asıl eksikliği Latin yazısından çok daha zor öğrenilmesinde bulunuyor. Türkler şöyle söylüyor; Batıda bir çocuk yedi sekiz yaşlarında bizde ise yaklaşık dokuz on yaşlarında okuma yazma ögreniyor. Öğrenmenin zorluğu Arap harflerinde Türkçe'ye uygun vokallerin direk bulunmamasındadır.

Mustafa Kemal Türk yazısının ilk reformcusu değildir. Enver Paşa da daha önce reform teșebbüsünde bulunmuştu. Fakat savaș döneminde söz konusu reform çabalart akamete uğramıştı. Bu teşebbüs için hem uygun zaman de ğildi hem de dini kesimin muhalefeti ve direnişi söz konusu

35 "Die latenische Schrift in der Türkei", Germania. 2 Kasım 1928. 
olmuştu. Ankara'nın yöneticilerinin Kemalist reformların uygulanabilmesi için dini kesimin etkilerini tamamen kırmayı başarmaları büyük bir olaydır. Mustafa Kemal'in gerçekten halka tamamen tesir etmeyi să̆laması başartyı getirdi. Enver Paşa savaş sırasında dini çevrelerin düşmanlığından korkmuştu. Mustafa Kemal Asyalı halkına egemen olmayı başardığı gibi emirlerini yerine getirecek heyecanlt ve büyük bir kitleyi arkasına takmayt da başardı. Hiçbir din adamı da başka bir tez ile karşısına çıkamaya cesaret edemedi. Böylelikle Türkiye Cumhuriyeti Devletinin de reformlar kolaylıkla gerçekleştirildi.

Türk Halkı'nın \% 80'den fazlası okuma yazma bilmiyordu. Diğer reformlar gibi yazı reformu da gerekliliğine inanılarak kabul edildi. Eğitimli kişiler bu adımın medeniyet yolunda taşıdı ğı anlamın bilincindedirler". Yazar, Atatürk'ün inkılâp sırasındaki stratejisini de şöyle anlatmaktadır. “...1928 yaz sonunda Ankara'da değişimi uygulamak için zamanın geldiği düşünüldü. Kemal Paşa ve arkadaşları yaz boyunca, Kasımda toplanacak olan meclis için Harf İnkılâbı ile ilgili yasa taslağı hazırladılar. Mustafa Kemal aynı zamanda bürosunda ve özel hayatında Latin harflerini kullanmaya başladı. Bakanlar önderlerini izledi. Bunu bazı ticaret odaları, Frankfurt'taki Türk-Alman ticaret odası takip etti. Gazeteler de ilk sayfalarında Latin harfleri ile yazılmış bazı bölümler açtılar. Devlet başkanının halkın yapısına uygun olarak attı $\breve{g}$ a adımlar ve tedbirlerin yanında örnekliği de çok önemliydi. Mustafa Kemal bunun için propagandayı başlattıktan sonra, bütün seyahatlerinde ve karşılamalarda her sinı memurlara ve halkın içinde sıradan insanlara yeni yazı işaretlerini anlatma ve birkaç kelimenin yazılışın öğretme fırsatını kaçırmadı. Nitekim başarl da gecikmedi. Yasa ilk günün serbest oturumunda Meclise getirildiğinde, halkın bu reformu nasıl kabul edeceği sorusu ortadan kalkmıştı. Basın ve kamuoyu buna çoktan "evet" demişti ki, geriye Parlamentoya bunu sadece onaylamak kalmıştı..." Yazı şu satırlarla son buluyor; "Kemal Paşa'nın Yazı reformunun gelecek günlerde kesinlikle başarı sağlayacağından ve kültürel gelişmelere yol açacağına şüphe yoktur. Şimdi yeni Türkiye ile ilgili olarak çok söz söylenebilir: Eski yıkıltyor, zaman değişiyor ve yıkıntılar içerisinden yeni bir hayat başlıyor" ${ }^{" 36}$.

Türk Alman Dostluk Derneği bülteninde "Türk medenileşme programında önemli bir adım, Latin Alfabesi" başlığı altında yayınlanan yukarıdaki satırlar, gerçekten dost bir ülke sıcaklığını taşımasının yanında, Türk harf inkılâbını süzen bir dikkatin izlerini de taşımaktadır. Mustafa Kemal ile Enver Paşa'nın mukayesesinde dikkat çekici bilgiler verilmektedir. Mustafa Kemal'in alfabe değişiminde uyguladığı strateji ve uygulamaları da çok iyi gözlemlenmiștir. Mustafa Kemal'in başarı dinamikleri ortaya konulmuş, harf inkılâbının gerek Türkler açısından

${ }^{36}$ Karl Klinghardt, "Dic Lateinschrift, ein bedeutsamer Schritt im türkischen Zivilisierungsprogramm" Mitteilungen der Deutsch-türkischen Vereinigung, Nr. $11 / 12$, November/Dezember Berlin 1928, wirtschafticher-Politischer Teil. 
gerekse batılılar için meydana getireceği olumlu etkiler açıklanmış ve yorumlanmıştır.

\section{SONUÇ}

Harf inkılâbımız ve harf inkılâbımızı hazırlayan şartlar Almanlar tarafından çok yakından takip edilmiştir. Gerek diplomatik kaynaklarda, gerek Alman basınında gerekse sair Alman kaynaklarında harf inkılâbımızla ilgili materyal bulmak mümkündür. İncelediğimiz Alman kaynakları harf inkılâbımıza müspet bir yaklaşım olduğunu göstermektedir. Ancak yine aynı kaynaklar, harf inkılâbının yaratacağı sorunları da büyük bir açıklıkla ortaya koymaya çalışmaktadır. Onlar da başarılacağından zaman zaman kuşku duydukları bu inkılâbın, ancak Atatürks gibi bir lider tarafından başarılabileceğini yaşayarak öğrenmişler ve hakkı teslim etmişlerdir. Latin harflerinin en yılmaz savunucuları bile Meşrutiyette değil, Cumhuriyet'te Atatürk'ün önderliğinde yürürken inkılâbın doğuracağı sonuçlar konusunda endişeye düşmüşlerdi. Ali Canip (Yöntem)'den Ali Ekrem (Bolayır)'a Avram Galanti (Bodrumlu)'den Halit Ziya (Uşaklıgil)'e kadar nice ünlü, harf inkılâbının yanlış olduğunu savundular. Fakat inkılâptan sonra olabilirliği ve pratik faydaları ortaya çıktığında da inkılâpların savunucusu oldular. Bu nedenle bir yazar, "Yazı Devrimini Kavrayamayanlar" başlıklı makalesine, "Yazı Devrimine Karşı Çıkanlar" başlığı verecekken, karșı çıkanların sonradan devrime yardımcı olduklarını düşünerek kavrayamayanlar, demeyi uygun bulduk demektedir. ${ }^{37}$ Böyle bir vasatın yaşandığı yerde, her yapılanı ve yazılanı adım adım takip eden Almanların Türkiye'de yaşanan psikolojiyi ve tereddütleri diplomatik raporlarına ve diğer kaynaklarına yansıttıkları görülmektedir.

Alman kaynaklarından çıkan diğer bir önemli sonuç da harf inkılâbının pratikte kendilerine sağlayacağı menfaatlerin değerlendirilmesidir. Kendi alfabe sistemlerini telkin ederek, bu reformdan kültürel nüfuz ve ekonomik çıkar uman Almanlar, bu süreçte özellikle Fransızların öne çıkma ihtimalinden rahatsızlık duymuşlardır.

Harf inkılâbımız batılı ülkeler tarafından genellikle olumlu tepkiler almıștır. Alman kaynaklarında da bu olumlu izleri açıkça görüyoruz. Türkiye'de olanları büyük bir hayranlıkla izleyen Almanlar, ülkeyi inkılâpları ile büyük bir değişim ve gelişim sürecine sokan Mustafa Kemal Atatürk'ü de değerlendirirken, sanki onun tarihteki müstesna yerini o günden belirleme hassasiyetini göstermişlerdir. Örneğin harf inkılâbı hakkında Ingilizlerde hakarete varan olumsuz değerlendirme örneğine rastlamak

${ }^{37}$ Sami N Özerdim. "Yazı Devrimini Kavrayamayanlar" Türk Dili Dergisi, S. 326. Kasım 1978 TDK. Ankara (s.582-589) Aynı makale 1979 yılında DTK yayınlarında Yazı Devrimi adlı cserde s.70-83 yayımlanmıștır. 
mümkünken $^{38}$ Alman kaynaklarında bu tür değerlendirmelere rastlanmamaktadır.

İnkılabın köklü ve kontrollü bir kültür değişmesine yol açacağı, ve bu değișmeden milli bir bilinç çıkartılmak istendiği, amacın yüzyılların ağır tortuları içinden çağın gereği olan “Türk Ulusu”nu yaratmaya matuf olduğu Alman kaynaklarınca da belirlenmiştir. Bu durumu inkılâbın uygulayıcılarından olan İsmet İnönü' $\mathrm{de}^{39}$ Arap kültürü'nden koparak bir kültür değişmesi meydana getirilmek istendiğini söyleyerek açıklamaya çalışmıştır. Çağdaş bir Alman kaynağı da inkılâbın bu özelliğini ve varılan sonuçları doğrulamaktadır. Alman bilim adamı Laut, radikal Kemalist reformların başarısının aynı zamanda Osmanlı geçmişi ile aynı zamanlı kopuşla mümkün olabileceğini, bunu başarabilmek için de gerçekçi hedefin, Arapça ve Farsça'dan kopmak ve Türk dilini kendi araçlarıyla yenilemek olduğu sonucuna vardığını söylemektedir. ${ }^{40}$

Harf İnkılâbı vesilesiyle yapılan yorumlarda Atatürk'ün inkılâpçı kişiliği, lider özellikleri, çağının çok önündeki fikir ve görüşleri ve bir strateji dehası olarak olaylara yön vermesi gibi meziyetleri Alman kaynaklarında yer almıştır.

\footnotetext{
${ }^{38}$ Sonyel, agm, s.292.

${ }^{39}$ İsmail Arar, "Gazi Alfabesi", Harf Devrimi'nin 50. Yılı Sempozyumu, TTK Ankara 1981 s149.

40 Jens Peter Laut, Das Türkische als Ursprache. Sprachwissenschaftliche Theorien in der Zeit des erwachsenden türkischen Nationalismus, Wiesbaden 2000, s.24. Son dönem Alman araştırmalarında da Türk dili ve alfabe problemlerine dair çalıșmalar yapılmaktadır. O çalışmalardan biri olan bu eserin 1. bölümünde Osmanlı Devleti'nde dilde reform çalışmaları özetlenmiş ve 1860'lardan Atatürk'e kadar olan dönemdeki reform tartışmaları süreci kaleme alınmıştır.
} 